\title{
Adding to the Toolkit: \\ Three Conceptual Tradeoffs
}

\author{
A Monograph \\ by \\ Lt Col Christopher E. Austin \\ USAF
}

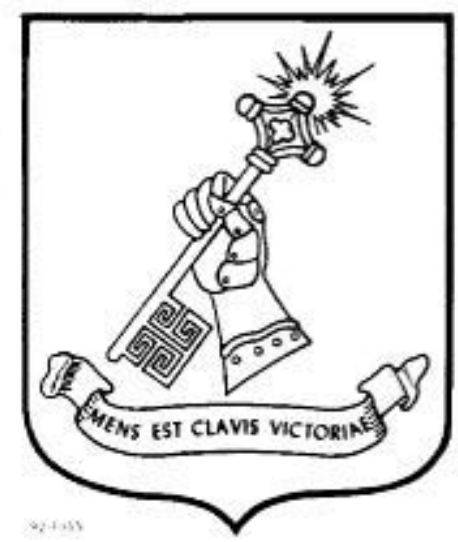

School of Advanced Military Studies

\section{United States Army Command and General Staff College \\ Fort Leavenworth, Kansas}

AY 2010 


\begin{tabular}{|c|c|c|c|}
\hline \multicolumn{3}{|c|}{ REPORT DOCUMENTATION PAGE } & $\begin{array}{c}\text { Form Approved } \\
\text { OMB No. 074-0188 }\end{array}$ \\
\hline \multicolumn{4}{|c|}{ 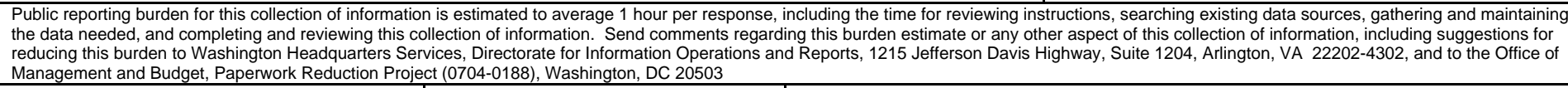 } \\
\hline $\begin{array}{l}\text { 1. AGENCY USE ONLY (Leave } \\
\text { blank) }\end{array}$ & 2. REPORT DATE & \multicolumn{2}{|c|}{ 3. REPORT TYPE AND DATES COVERED } \\
\hline \multicolumn{3}{|c|}{$\begin{array}{l}\text { 4. TITLE AND SUBTITLE } \\
\text { ADDING TO THE TOOLKIT: THREE CONCEPTUAL TRADEOFFS }\end{array}$} & 5. FUNDING NUMBERS \\
\hline \multicolumn{3}{|c|}{$\begin{array}{l}\text { 6. AUTHOR(S) } \\
\text { Lt Col Christopher E. Austin }\end{array}$} & \\
\hline \multicolumn{3}{|c|}{ 7. PERFORMING ORGANIZATION NAME(S) AND ADDRESS(ES) } & $\begin{array}{l}\text { 8. PERFORMING ORGANIZATION } \\
\text { REPORT NUMBER }\end{array}$ \\
\hline \multicolumn{3}{|c|}{ 9. SPONSORING / MONITORING AGENCY NAME(S) AND ADDRESS(ES) } & $\begin{array}{l}\text { 10. SPONSORING / MONITORING } \\
\text { AGENCY REPORT NUMBER }\end{array}$ \\
\hline
\end{tabular}

\section{SUPPLEMENTARY NOTES}

\section{ABSTRACT (Maximum 200 Words)}

This monograph shows how understanding three conceptual tradeoffs of complex versus complicated, complexity at large-scale versus fine-scale, and exploration of potential problems versus exploitation of known solutions can help the military practitioner better learn, anticipate and adapt to difficult problems. It does so by defining the three conceptual tradeoffs and then applying them to Operation Iraqi Freedom for the United States in 2003 and the Israeli incursion into Southern Lebanon by the Israeli Defense Forces in 2006. These difficult operations involved conventional, guerilla, counterinsurgency and irregular operations that provide two relevant examples to help the military practitioner better prepare for $21^{\text {st }}$ century operations.

\begin{tabular}{|c|c|c|c|}
\hline \multicolumn{3}{|l|}{ 14. SUBJECT TERMS } & \multirow{2}{*}{$\begin{array}{l}\text { 15. NUMBER OF PAGES } \\
39 \\
\text { 16. PRICE CODE } \\
\text { 20. LIMITATION OF ABSTRACT }\end{array}$} \\
\hline $\begin{array}{l}\text { 17. SECURITY CLASSIFICATION } \\
\text { OF REPORT } \\
\text { UNCLASS IF IED }\end{array}$ & $\begin{array}{l}\text { 18. SECURITY CLASSIFICATION } \\
\text { OF THIS PAGE } \\
\text { UNCLASS IF IED }\end{array}$ & $\begin{array}{l}\text { 19. SECURITY CLASSIFICATION } \\
\text { OF ABSTRACT } \\
\text { UNCLASS IF IED }\end{array}$ & \\
\hline NSN 7540-01-280-5500 & & & $\begin{array}{l}\text { ndard Form } 298 \text { (Rev. 2-89) } \\
\text { cribed by ANSI Std. Z39-18 } \\
102\end{array}$ \\
\hline
\end{tabular}




\title{
SCHOOL OF ADVANCED MILITARY STUDIES \\ MONOGRAPH APPROVAL
}

\author{
Lt Col Christopher E. Austin
}

Title of Monograph: Adding to the Toolkit: Three Conceptual Tradeoffs

Approved by:

Gerald S. Gorman, Ph.D.

Monograph Director

Second Reader

John J. Marr, COL, IN

Wayne W. Grigsby, Jr., COL, IN

Director,

School of Advanced

Military Studies

\author{
Director, \\ Graduate Degree \\ Programs
}

Robert F. Baumann, Ph.D.

Disclaimer: Opinions, conclusions, and recommendations expressed or implied within are solely those of the author, and do not represent the views of the US Army School of Advanced Military Studies, the US Army Command and General Staff College, the United States Army, the Department of Defense, or any other US government agency. Cleared for public release: distribution unlimited. 


\section{Abstract}

ADDING TO THE TOOLKIT: THREE CONCEPTUAL TRADEOFFS, by Lt Col Christopher E. Austin, USAF, 39 pages.

This monograph shows how understanding three conceptual tradeoffs of complex versus complicated, complexity at large-scale versus fine-scale, and exploration of potential problems versus exploitation of known solutions can help the military practitioner better learn, anticipate and adapt to difficult problems. It does so by defining the three conceptual tradeoffs and then applying them to Operation Iraqi Freedom for the United States in 2003 and the Israeli incursion into Southern Lebanon by the Israeli Defense Forces in 2006. These difficult operations involved conventional, guerilla, counterinsurgency and irregular operations that provide two relevant examples to help the military practitioner better prepare for $21^{\text {st }}$ century operations. 


\section{Table of Contents}

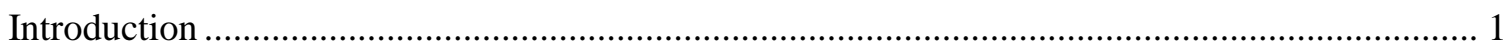

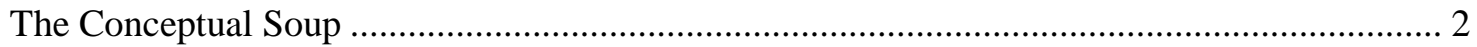

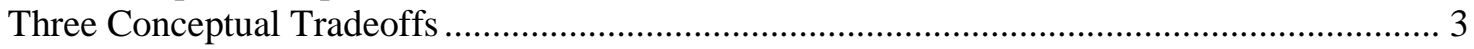



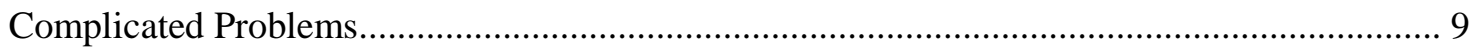

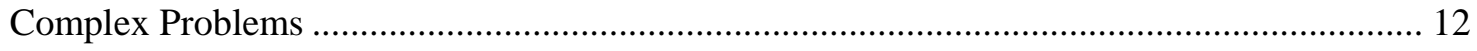

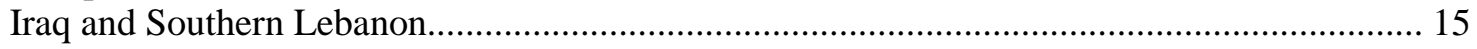

COMPLEXITY AT LARGE-SCALE AND COMPLEXITY AT FINE-SCALE ….................... 21

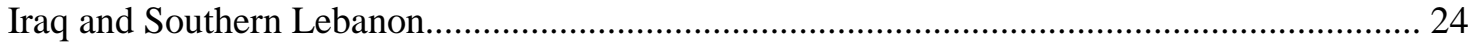

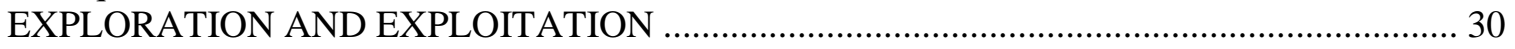

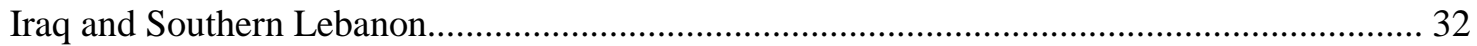

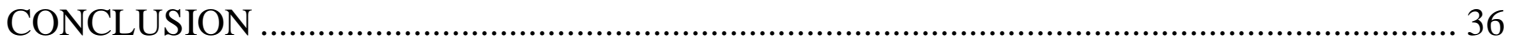






\section{Introduction}

“War consists of a continuous interaction of opposites." 1

Carl Von Clausewitz

"The future of the military profession may depend on finding a unity of opposites."2

Christopher E. Paparone

They were conceived to be dazzling displays of military prowess, yet became troubled military operations. The second American defeat of Iraqi military forces in twelve years occurred in March of 2003, culminating just a few weeks later with the fall of Baghdad. It was truly a "shock and awe" campaign, composed of firepower, intelligence, and technology against the Iraqi army. Within weeks after conventional operations ceased, however, Iraq fell into chaos. It became clear that US forces ${ }^{3}$ were not organized, trained and equipped for the population-centric operations required to stabilize the country. The war in southern Lebanon in the summer of 2006 was a flawed operation from the start for the Israeli Defense Forces (IDF), pitting the technologically competent forces of Israel against Hezbollah-- an “organized political movement with decentralized cells employing adaptive tactics in ungoverned zones." ${ }^{4}$ According to the Israeli Winograd Report, which evaluated the IDF after the war, the IDF

${ }^{1}$ Carl Von Clausewitz, On War (Princeton, NJ: Princeton University Press, 1976), 136.

${ }^{2}$ Christopher E. Paparone, "Design and the Prospects of a US Military Renaissance," Small Wars Journal (May 2010): 5-6, http://smallwarsjournal.com/blog/2010/05/print/design-and-the-prospects-of-a/ (accessed 27 June, 2010).

${ }^{3}$ Although the term "US forces" is used throughout the monograph, Operation Iraqi Freedom included military forces from Britain, Australia and Poland among others.

${ }^{4}$ Frank G. Hoffman, Conflict in the $21^{\text {st }}$ Century, The Rise of Hybrid Wars, (Potomac Institute for Policy Studies, 2007): 35, http://www.potomacinstitute.org/index.php?option=com_content\&view=article\&id=77:-conflictin-the-21st-century-the-rise-of-hybrid-wars\&catid=40:books\&Itemid=62 (accessed 27 June, 2010). 
performance was, "a result of a mixture of flawed conduct of political and military echelons, flawed performance of the IDF, and deficient Israeli preparedness.” ${ }^{5}$

These are troubling examples. In Iraq for the United States and in Southern Lebanon for Israel, two state-of-the-art and highly trained militaries were unprepared for the reality they faced in complex combat operations. As troubling as they both are, however, these two operations present learning opportunities for military practitioners. This monograph contributes to the discourse on how military organizations deal with complex situations by asking the question: are concepts taken from complexity theory useful in understanding military problems? Using the wars of the United States in Iraq in 2003 and Israel in southern Lebanon in 2006, this monograph shows that these concepts do indeed add utility in understanding military problems.

\section{The Conceptual Soup}

In their book Military Misfortunes, Eliot A. Cohen and John Gooch describe three types of failure related to military organizations: failure to learn, failure to anticipate and failure to adapt. ${ }^{6}$ In Iraq, US forces failed to anticipate what would happen after conventional operations ceased, yet were fortunate to have the time available, political backing and resources at their disposal to adapt to the conditions in Iraq with a population-centric counterinsurgency campaign. On the other hand, Israeli Forces were not so lucky in their war with Hezbollah in Southern Lebanon. The IDF failed to learn from its own past as well as from US difficulties in Iraq. It also failed to anticipate Hezbollah capabilities, and terminated the war with few of its strategic goals attained. This resulted in a "squandered opportunity to destroy the bulk of

\footnotetext{
5 The Winograd Commission, “The Winograd Report: The Main Findings of the Winograd Partial Report on the Second Lebanon War,” http://online.wsj.com/public/resources/documents/winogradreport-04302007.pdf (Accessed 10 Sep 2010).

${ }^{6}$ Eliot A. Cohen and John Gooch, Military Misfortunes: The Anatomy of Failure in War (New York; London: Free Press; Collier Macmillan, 1990), 26.
} 
Hezbollah’s military presence, settle regional scores (with Syria and Iran), enhance Israeli’s deterrence, and strengthen Jerusalem's alliance with Washington."7

The difficulty of the wars in Iraq and Southern Lebanon was not a result of a lack of theory or conceptual tools available to the military practitioner. A number of useful theories and concepts have come in and out of fashion in recent years. These include: Network Centric Warfare, Effects Based Operations, Systemic Operational Design, Operational Design (Design), Fourth Generation Warfare, Compound Warfare, Unrestricted Warfare, and Hybrid War, just to name a few.

While all the theories listed above have value, there exists no panacea to relieve the military practitioner of the difficult burden of understanding warfare. The best answer for the military practitioner may be to build a collection of theories and concepts, rather than a single one, to learn, anticipate and adapt to military operations in complex environments. As a toolbox with many tools gives the mechanic many options for differing jobs, multiple conceptual approaches gives the military practitioner many options for making sense of complex operations.

\section{Three Conceptual Tradeoffs}

Rather than providing a broad conceptual cure-all, this monograph assists the military practitioner by providing three conceptual tradeoffs that can enrich the understanding of how organizations, more specifically military organizations, can better learn, anticipate and adapt to complex environments. This monograph shows how an understanding of complex problems versus complicated problems, organizational orientation towards complexity at large-scale versus fine-scale, and organizational exploration versus exploitation provides insight into military problems. These conceptual tradeoffs will be applied to the conflicts in Iraq for the United States and Southern Lebanon for Israel, to help the military practitioner to prepare for future operations.

\footnotetext{
${ }^{7}$ Efraim Inbar, “How Israel Bungled the Second Lebanon War,” Middle East Quarterly, Summer, 2007, http://www.meforum.org/1686/how-israel-bungled-the-second-lebanon-war (accessed 21 June, 2010).
} 
The first section of this monograph describes the difference between complex and complicated problems and the implications of how an organization favors orientation towards one at the expense of the other. Although it would be a gross oversimplification to say that a military problem is either complicated or complex, understanding the difference between the two can shed light on military problems. Military organizations orient to problems in certain ways that can challenge their ability to manage problems in other ways. The tradeoff in orienting between complicated and complex problems is one such example.

Complicated problems, which are problems subject to reductive mechanistic analysis, can be more easily understood, controlled and predicted. Thus organizations that focus on efficiency and optimization with hierarchical control structures tend to manage them best, but can fall victim to surprise if the situation becomes unpredictable. Complex problems, which are not as predictable due to interdependencies and feedback, are like moving targets. Thus organizations that learn, anticipate, and adapt with distributed control structures manage them best, but can struggle with internal efficiency because of their distributed structure. This tradeoff is relevant to military problems because it affects how military organizations orient for conflict. If an organization is not oriented properly for the type of problem it faces, it struggles to manage that problem.

This was the case for both the United States in Iraq and Israel in Southern Lebanon. Both had difficulty in their respective conflicts, because both aligned their forces to problems they were not organized, trained and equipped for. US forces dominated the Iraqi army in firepower and maneuver but were unprepared for the complexity associated with population-centric stability operations. This was made especially problematic after removal of the Iraqi government forces (de-Baathification), which added even more complexity to the military problem when Iraq lost its functioning governmental infrastructure. The IDF anticipated that airpower could target and react fast enough to silence Hezbollah rocket attacks without the need for a large land campaign. Unfortunately for Israel, this was a flawed assumption as Hezbollah successfully used distributed operations to continue rocket attacks throughout the conflict. These distributed operations introduced a level of complexity that IDF airpower was not capable of dealing with. 
The second section of this monograph describes the difference between how an organization orients for complexity at a large-scale versus complexity at a fine-scale. While the tradeoff of complicated versus complex has to do with predictability and linearity, the tradeoff of large-scale versus fine-scale has to do with parts acting together for coordinated action. According to Yaneer Bar-Yam, "scale refers to the number of parts of a system that act together in a strictly coordinated way."8 Large-scale does not necessarily imply big; rather it is the choice to orient a fixed number of parts of an organization to act together in a coordinated way to mass effects. An example of orienting to complexity at a large-scale is the Roman Legion. Composed of approximately 5000 men, each part of a Roman Legion specialized in operations that better enabled the whole to work together as one. In large-scale type battles, the better the Roman Legion worked as one, the more effective it was.

Fine-scale involves using parts not to act in concert, but in distributed ways to amass many different effects simultaneously. The unit remains coordinated so as to have shared identity, but the parts operate in ways that are independent of other parts. An example of this is a US Special Operations team such as a US Navy Seal Team. While it remains an organization of approximately 2,600 personnel, the parts may be scattered all over the world doing missions unrelated to each other. Their specialty is distributed, uncoordinated operations to penetrate into fine-scale complexity. Both large-scale and finescale operations are useful to modern militaries, which contain a balance of both. Organizations can reorient from large-scale to fine-scale, but in the modern military context, this can be a massive undertaking and there may not be time or resources available to do so.

US forces in Iraq were oriented for a large-scale campaign to overwhelm the Iraqi military. US forces effectively massed effects on a larger scale than the Iraqi military could defend against and won a quick decisive victory. Once the war shifted to a population-centric conflict requiring an orientation to complexity at the fine-scale however, US forces were unprepared. Not until US forces adapted with a new

8 Yaneer Bar-Yam, Multi-scale Representations Phase II (New England Complex Systems Institute, March, 2004), 100, http://handle.dtic.mil/100.2/ADA423165 (accessed 27 Aug 2010). 
counterinsurgency campaign and oriented towards the fine-scale complexity of a population-centric fight were they able to turn the tide of the war. The IDF's ground forces in Southern Lebanon struggled because they were overly oriented for fine-scale operations after numerous years conducting populationcentric operations in Palestine. Once the war began, they were not able to conduct combined arms warfare or mass firepower quickly enough to match that larger-scale opposition presented by Hezbollah and took startling casualties.

The third section of this monograph compares the organizational tradeoff between exploration and exploitation. Organizations must balance agents within their organizations to a degree that allows exploration of potential problems as well as exploitation of known solutions. When a military force has not explored ways to handle problems that its enemy has the ability to exploit, asymmetric advantage results. On the other hand, a military force gains advantage when it exploits a situation better than its enemy. The United States in Iraq exploited its conventional advantage over Iraqi forces in the "shock and awe” campaign, but was not prepared for population-centric operations. This was because US forces institutionally focused on exploitation of large-scale conventional operations instead of exploring how to succeed in fine-scale population-centric operations. Once US forces took the time and allocated the resources to explore required ways and means to succeed in population-centric operations, the war began to shift in their favor. For the IDF in Southern Lebanon, it was Hezbollah that in the previous six years had explored new strategies to exploit advantage against the IDF, while the IDF falsely anticipated it would be able to exploit its advantage in airpower, firepower and rapid targeting. 


\section{COMPLICATED VERSUS COMPLEX PROBLEMS}

"The test of a first-rate intelligence is the ability to hold two opposing ideas in the mind at the same time, and still retain the ability to function."

\section{F. Scott Fitzgerald}

No military problem should be defined only as complicated or complex. In the paper Integrated Planning: The Operations Process, Design, and the Military Decision Making Process, Colonel Wayne Grigsby asserts: “Once one moves from the abstract, theoretical problem, to a real world version of the same problem, complexity immediately rears its ugly head. Any problem that involves predicting the behavior of human beings is inherently complex."10 It is true that every problem involving human behavior involves an element of complexity, but it is not useful to call it inherently complex. It is more useful to give a condition to the complexity or to compare it to something else. Although it is true that predicting the behavior of human beings involves complexity, it is an oversimplification to call the behavior only complex. Many problems have differing levels of complexity and some are not complex at all, they are complicated, simple, or even chaotic. To understand that problems involve more than just a black and white description involving a blend of conditions, leads the military practitioner to a higher level of understanding problems. This is an important distinction because how an organization defines a problem dictates how it orients towards that problem. A better way to define problems that involve predicting human behavior would be to suggest that they are a blend of tradeoffs. The tradeoff between complicated and complex is one of these useful tradeoffs.

The delineation between complicated and complex problems provides a conceptual vehicle in which to understand that different types of problems require different ways and means with which to

${ }^{9}$ F. Scott Fitzgerald. “The Crack Up,” Esquire Magazine, February 26, 2008, http://www.esquire.com/features/the-crack-up (accessed 26 Sep 2010).

${ }^{10}$ Wayne W. Grigsby, Scott Gorman, Jack Marr, Joseph McLamb, Pete Schifferle, and Michael Stewart. Integrated Planning: The Operations Process, Design, and the Military Decisions Making Process. (Fort Leavenworth, KS: School of Advanced Military Studies Handout, 2010), 2. 
understand them. Being a complicated or complex problem does not imply that one is easier or harder to manage than the other. They are just different. Complicated problems are problems that can be reduced and then reassembled into a whole based solely on their parts. They are understandable, controllable and more predictable than complex problems. Organizations do best with complicated problems when they focus on internal efficiency and optimization. Complex problems are not as predictable due to interdependencies and feedback. Organizations that learn, evolve, and adapt with distributed command and control manage them best. Although the ends may be the same, the ways and means to solve complex versus complicated problems are different. Understanding the difference between the two types of problems, and how the United States and Israel had difficulty, can be useful for learning from, anticipating and adapting to military problems.

The word complicated includes the Latin root, "plic,” which means to fold, while the word complex includes the Latin root, "plex,” which means to weave. ${ }^{11}$ To unfold a complicated problem into multiple components is to enable reductive analysis, which deconstructs the parts of a problem and then reassembles them into the original whole. To reduce the woven parts of a complex problem into individual components does not provide insight into the whole, just like the pattern of a woven blanket is not visible in the individual threads. Therefore, the interdependencies of the parts are not clear from the parts themselves, and the parts alone cannot reassemble the whole without the interdependencies included.

Colonel Christopher Paparone distinguished complicated problems from complex problems comparing the Greek philosophers Parmenides and Heraclites. In his essay titled, “Design and the Prospects of a Military Renaissance," Paparone described the world viewed by Parmenides as the objective world of scientific reproducibility, ruled by concrete knowledge and nomotheticism, or the philosophy of seeking irrefutable laws. The world described by Heraclites, on the other hand, was the

\footnotetext{
${ }^{11}$ L. J. Vandergriff, “Complex Venture Acquisition,” Symposium on Complex Systems Engineering (Santa Monica, CA: RAND, 2006), 10.
} 
subjective world of uniqueness, locality, novelty, and conceptualism. Parmenides described the world as complicated, linear and what some experts today call Newtonian; the world according to Heraclites was complex, non-linear and modeled the concept of homeorhesis (fluctuating instability, where causality is impossible to pin down. $)^{12}$

Clausewitz appreciated the complicated aspects of warfare, but he also appreciated its complex aspects as well. For him, managing complex problems involved subjective brilliance or genius, in addition to the requirement for objective knowledge. According to Antulio Echevarria, Clausewitz realized he could not describe all objective knowledge about warfare, but he could push the objective discourse of military theory farther than it had been. For Clausewitz the basis of subjective brilliance, or genius, began with objective truth. Mr. Echevarria wrote that according to Clausewitz, "objective knowledge supplied a foundation for an individual's self-education, for the cultivation and development of subjective knowledge." ${ }^{13}$ Clausewitz also understood that even through the fog, friction and chaos of warfare, genius could help to sort through the mess and find objective realities. According to Clausewitz,

"The man responsible for evaluating the whole must bring to his task the quality of intuition that perceives the truth at every point. Otherwise a chaos of opinions and considerations would arise, and fatally entangle judgment. Bonaparte rightly said in this connection that many of the decisions faced by the commander-in-chief resemble mathematical problems worthy of the gifts of a Newton or an Euler." 14 The reality of military problems is that they contain elements that are both complex and complicated; therefore a more detailed description of each of these characteristics is useful.

\section{Complicated Problems}

It is possible to understand complicated problems much like one can understand a machine. Input and output can be observed, measured, analyzed and then predicted for the future. Also, as the amount of

\footnotetext{
12 Paparone, 3.

${ }^{13}$ Antulio J. Echevarria, Clausewitz and Contemporary War (Oxford, England: Oxford University Press, 2007), 32.

${ }^{14}$ Clausewitz, 112.
} 
input is increased or decreased, the amount of output increases or decreases in a predictable manner.

Complicated problems are thus linear; linearity is the fundamental basis of Newtonian mathematics. John F. Schmitt writes,

"The Newtonian paradigm is the product of the Scientific Revolution which began in the 16th century...[it] is the mechanistic paradigm: the world and everything in it as a giant machine. The preferred Newtonian metaphor is the clock: finely tooled gears meshing smoothly and precisely, ticking along predictably, measurably and reliably, keeping perfect time.”15

According to Alan Beyerchen, complicated problems involve a system of input/output variables that can be plotted along a straight line on a graph that conform to the principle he calls proportionality. Proportionality is a product of a system in which input equals system output across scale, a concept economists call “constant returns to scale.” Mr. Beyerchen notes that linear systems also have a property known as additivity. Additivity is where the whole of a system equals the sum of its parts, allowing the parts to be separated, analyzed and put back into the whole. ${ }^{16}$

All military practitioners strive to make warfare as predictable as possible. With additivity and proportionality, problems become just that-- predictable. Once the solution to a problem becomes predictable, the full weight of effort and orientation of a military can be directed at solving that problem along its linear path. This leads to solutions that involve efficiency and optimization. According to Schmitt, once military practitioners see predictable linearity in the conduct of warfare, warfare by calculation takes over. "In the Newtonian view, linearity is a good thing because linear systems are tame

${ }^{15}$ John F. Schmitt, “Command and (Out of) Control: The Military Implications Theory,” in Complexity, Global Politics, and National Security, ed. David S. Alberts and Thomas Czerwinski (Washington DC: National Defense University, 1997) http://www.au.af.mil/au/awc/awcgate/ndu/complexity/comch09.html (Accessed 15 April, 2010).

${ }^{16}$ Alan Beyerchen, “Clausewitz, Nonlinearity, and the Importance of Imagery," in Complexity, Global Politics, and National Security, ed. David S. Alberts and Thomas Czerwinski (Washington DC: National Defense University, 1997),62, http://www.au.af.mil/au/awc/awcgate/ndu/complexity/comch07.html (Accessed 15 April, 2010). 
and controllable; they do not do unexpected things. If you know a little about a linear system you know a lot, because if you know a little you can calculate the rest.”17

If a problem is perceived as being complicated, organizations attempt to exploit it by focusing on reductionism and internal efficiency. This focus enables organizations the best cost-benefit tradeoff for solving the problem, because the organization can unleash more of its resources to a predictable result. Predictability therefore becomes a huge advantage in military operations. Because of this, there is a long history of militaries attempting to harness linearity and predictability in warfare. Two examples of this are Lanchester Equations and the Dupuy Quantified Judgment Model. Lanchester Equations, developed during World War I by Fredrick Lanchester, present differential formulas that describe the time dependence of attacker versus defender strengths, and were used to mathematically predict military advantage. ${ }^{18}$ Colonel Trevor Dupuy created the Dupuy Quantified Judgment Model in the 1960s. His studies began in 1964 and involved processes to compare the lethality of weapons over the course of history to create a predictive model. ${ }^{19}$

When organizations orient towards complicated problems, they get the most benefit by focusing on internal efficiency and optimization. To focus on efficiency and optimization, an organization must focus internally on processes and procedures, and the best way to streamline internal operations is through hierarchical structure. Because of this, organizations that are hierarchically structured tend to do best at complicated problems.

This presents a problem however for military operations. The problem with hierarchically controlled organizations is their lack of adaptability and potential for innovation. This can open the

17 Schmitt, 3.

${ }^{18}$ Paul K. Davis, Aggregation, Disaggregation, and the 3:1 Rules in Ground Combat (Santa Monica, CA: RAND, 1995), 29.

${ }^{19}$ Susan Rich. “Trevor N. Dupuy biography,” The Dupuy Institute, http://www.dupuyinstitute.org/tndupuy.htm (accessed 24 Sep 2010). 
organization up to being caught by surprise by problems that do not fall into a predictive model. As

Robert R. Maxfield notes,

"Staff organizations spend endless hours worrying about the "best" way to organize people into functional blocks, how these blocks should relate and communicate, designing "optimal" work flows and methodologies (aided by systems and operations research theorists). By their very design, such organizations do not allow for rapid adaptivity and innovation in response to external change.”20

In military operations, this can be a tremendous problem. Warfare by calculation, although it may give military advantage in certain specific circumstance, is a recipe for surprise or even worse, military disaster. The more that a military organization orients towards complicated problems, the more efficient and optimized it is for those specific problems. If a problem set comes along that the organization is not optimized for, the organization remains unprepared, thus vulnerable. Warfare is problematic for military organizations because it occurs between enemies and environments that are constantly changing. Because of this, optimization only for complicated problems can create a blind spot for an organization.

Clausewitz argued that warfare is constantly changing. In On War he writes,

"Efforts were therefore made to equip the conduct of war with principles, rules, or even systems. This did present a positive goal, but people failed to take adequate account of the endless complexities involved. [These attempts] aim at fixed values; but in war everything is uncertain, and calculations have to be made with variable quantities. They direct the inquiry exclusively toward physical quantities, whereas all military action is entwined with psychological forces and effects. They consider only unilateral action, whereas war consists of a continuous interaction of opposite.”21

\section{Complex Problems}

Clausewitz had it right when he talked about warfare constantly changing. One way in which warfare constantly changes is through complexity. Complex problems are like moving targets. Complex problems, as opposed to complicated problems, do not lend themselves to proportionality, additivity, or predictability. Because of this, organizations must orient their ways and means to be adaptable to non-

${ }^{20}$ Robert R. Maxfield, “Complexity and Organization Management,” in Complexity, Global Politics, and National Security, ed. David S. Alberts and Thomas Czerwinski (Washington DC: National Defense University, 1997) http://www.au.af.mil/au/awc/awcgate/ndu/complexity/comch08.html (Accessed 14 June 2010).

${ }^{21}$ Clausewitz, 134, 136. 
linearity and unpredictability, constantly re-inventing new ways of looking at problems. Thus organizations that learn, evolve, and adapt with distributed control structures manage them best. Focus points for managing complex problems shift away from efficiency and optimization and more towards adaptability and feedback.

The scientist Yaneer Bar-Yam defined complex systems as "formed of multiple interacting elements whose collective actions are difficult to infer from those of the individual parts, predictability is severely limited, and response to external forces does not scale linearly with the applied force.”22 As implied by the Latin root “to weave," complex problems are not subject to reductive mechanistic analysis because of the inherent interdependencies and feedback of the agents.

Feedback is an important aspect of complex problems because, more so than for complicated problems, complex problems involve learning and evolution which depend on feedback-based interactions. This creates non-linearity in input/output comparisons, and forces an organization to adapt to conditions as they change. Sun Tzu noted this need for adaptability: "Water configures its flow in accord with the terrain; the army controls its victory in accord with the enemy." ${ }^{23}$ Clausewitz later added "War, however, is not the action of a living force upon a lifeless mass, but always a collision of two living forces.”24 Because of feedback, orientation towards adaptation is required for organizations to effectively manage complex problems. As described by Schmitt, in a complex environment, command and control requires continuous learning and adapting for organizational survival.

"In a complex, open environment, command and control is fundamentally a process of continuous adaptation. We might better liken the military organization to a predatory animal—seeking information, learning and adapting in its desire for continued survival-than to some "lean, green machine." Most military actions do not proceed with clockwork mechanics—as operations." 25

${ }^{22}$ Yaneer Bar-Yam, Making Things Work: Solving Complex Problems in a Complex World (Cambridge, MA: NECSI, Knowledge Press, 2004), 1.

\footnotetext{
23 Sun Tzu, The Art of War (Oxford, Westview Press, 1994) 140.

${ }^{24}$ Clausewitz, 77.

25 Schmitt, 4.
} 
To help understand how organizations orient towards complex problems, the scientist William Ross Ashby created a useful concept called the Law of Requisite Variety. It states that a problem can only be controlled if the variety of the controller matches the variety of the situation to be controlled. ${ }^{26}$ Put another way, the complexity of a task must be matched by the complexity of a system trying to perform the task effectively. According to Bar-Yam, "high complexity biological organisms exist because simpler organisms are less likely to survive. While human designed systems, such as military ones, might sometimes be built with unnecessary complexity, still, when a high complexity task exists, only a high complexity system can perform it.”27 Thus to control a complex problem, an organization must possess an equal to or greater number of answers to questions than the problem can present. This has tremendous implications for military organizations that function in highly complex environments.

Because of the Law of Requisite Variety, organizations that need to increase internal complexity and become more adaptable use distributed versus hierarchical command and control systems. Hierarchical command and control systems are limited by what Bar-Yam calls, "bandwidth.” If an organization is hierarchically controlled, it can only become as complex as the control system in place. If it is entirely controlled by one person, with all decisions going through that one person, then the organization can only handle the level of complexity that the person can. Therefore, the complexity an organization can handle is limited by the complexity of the command and control system that it possesses. ${ }^{28}$ Because of this, hierarchical command and control systems struggle in complex operations, while distributed command and control systems do better in complex operations.

So why don’t military organizations automatically orient towards complex operations with distributed command and control systems? One reason is that they become difficult to manage internally.

\footnotetext{
${ }^{26}$ Allenna Leonard, “A Response to the Discussion of the Community of Systems Thinkers and Cyberneticians” (lecture, September 21, 2001), http://www.isss.org/911/leonard.htm (accessed 24 Sep 2010).

${ }^{27}$ Yaneer Bar-Yam, Complexity of Military Conflict: Multiscale Complex Systems Analysis of Littoral Warfare (New England Complex Systems Institute, 2003), 3.

${ }^{28}$ Ibid, 8.
} 
According to Dr. Alex Ryan, “The greater the complexity of one’s own system, the greater the internal friction between components. Complexity is the common source of system incoherence, inter-scale conflict and cascading future. ${ }^{29}$ Much as hierarchically controlled organizations are able to focus on efficiency and optimization, the more distributed the command and control of an organization, the less efficient it becomes, despite its potential ability to manage more complexity. Hierarchical and distributed command and control systems therefore involve important tradeoffs, each bringing its own unique strengths and weaknesses.

\section{Iraq and Southern Lebanon}

US forces in Iraq in 2003 and Israeli air forces in Southern Lebanon in 2006 provide two examples of organizations that were not properly oriented for the problems they faced in their respective conflicts. US forces dominated conventional operations against the Iraqi military, conducting a quick and decisive campaign. When the operation shifted to population-centric operations, US forces began to falter. This problem was made even more difficult with the removal of the Iraqi government (de-Baathification), which added more complexity to the military problem. The IDF anticipated incorrectly that airpower could target distributed Hezbollah rocket units and was unwilling to send in enough ground forces to quell the rocket attacks. In each case, there exists a cogent example of organizational misorientation to the level of complexity required to match the problem presented. The forces struggled by not being as complex as their respective problems.

For the United States in Iraq in 2003, the success of the conventional campaign to defeat Iraqi military forces was impressive. Along with British, Australian and Polish forces, US forces began operations on 20 March 2003 and succeeded in the final defeat of Iraqi conventional forces on 9 April.

\footnotetext{
${ }^{29}$ Alex J. Ryan, “Military Applications of Complex Systems,” in Philosophy of Complex Systems, ed. Dov M. Gabbay, Cliff Hooker, Paul Thagard, John Collier and John Woods (Amsterdam, Netherlands: Elsever, 2010), 781.
} 
All in all, coalition forces sustained 122 American and 33 British deaths against an Iraqi force of 200,000 personnel, 2000 tanks, 2000 armored personnel carriers, 150 self-propelled artillery guns, and 2000 towed guns. ${ }^{30}$ The coalition defeat of Iraqi forces in twenty-one days was what the esteemed military historian John Keegan called, “a lightning campaign so complete in its results almost unprecedented. For comparisons, one has to reach back to the cabinet wars of the nineteenth century, Prussia's victory over Austria in 1866 to over the French in less than a month in 1870.”31 Soon after conventional operations ceased, President George W. Bush proclaimed victory: “in the Battle of Iraq, the United States and our allies have prevailed.” ${ }^{32}$ However soon after his speech, it became clear that success for the United States was not as simple as a conventional military victory. Within months, Iraq fell into chaos.

Unfortunately, the United States policy towards Iraq adopted what John Keegan called an “ideological approach” to post-conventional operations; “They sought an immediate transformation of Iraq from a tyranny to a functioning democracy." ${ }^{33}$ With the Office of Reconstruction and Humanitarian Assistance under Jay Garner and the Coalition Provisional Authority under Paul Bremer, the United States adopted a policy of disassembling the functioning Iraqi governmental infrastructure through deBaathification and dismissing police and military forces. De-Baathification was the process of removing members of Saddam Hussein's former regime down up to five and six levels in the former government.

This prevented the personnel who possessed the expertise for running Iraqi government from governmental work and created a more complex problem for US forces. As Jay Garner said in an after action interview, "You think about going that far in our government and removing everybody. How

\footnotetext{
${ }^{30}$ John Keegan, The Iraq War (New York, NY: Vintage Books, 2005), 204.

${ }^{31}$ Ibid, 1.

32 Jarrett Murphy, "President Declares End to Major Combat Operations in Iraq,” CBS Newsworld (May 1, 2003), http://www.cbsnews.com/stories/2003/05/01/iraq/main551946.shtml (retrieved on 16 Jun 2010).

${ }^{33}$ Keegan, 209.
} 
efficient do you think the remaining government would be? Not very efficient...This was a mistake.»34 Another mistake identified by Garner was not bringing back the Iraqi Army and to dismiss the Iraqi Ministry of Defense. With these decisions, 250,000 unemployed personnel were released into Iraqi society and Iraq no longer had the ability to manage itself. ${ }^{35}$ According to Jeffrey Record, these decisions were calamitous:

"From the beginning, US strategy has been seriously hampered by what critics across the political spectrum agree are several interrelated errors: an insistence on providing for only a small invasion force that ignored potential demands for policing post-Baathist Iraq; lack of planning for post-Baathist Iraq; failure to consider that destroying the Baathist regime could also collapse the Iraqi state (the two were virtually synonymous), producing a catastrophic success; and failure to anticipate the likelihood of an extended US occupation of Iraq and insurgent resistance to it.”36

Soon after these decisions were made, Iraq began to spiral out of control as there no longer existed a government in Iraq or a security force to maintain it. Iraqi police forces disappeared from the streets and anarchy began to take hold. This became especially bad in the Sunni region where ex-Saddam militiamen, also called fedayeen, as well as foreign fighters, began an insurgency. Although eighty per cent of Iraqis favored Saddam Hussein's downfall, a difficult situation began to present itself in Iraq. ${ }^{37}$ As described by the military strategist David Kilcullen, the situation in Iraq became an extremely complex conflict. "Iraq is not just an insurgency; it is an insurgency plus a terror campaign, plus a sectarian civil war, sitting on top of a fragile state within a divided unstable region.”38

Because of all of this, the nature of the problem changed, requiring a reorientation of US forces and strategy. The situation shifted from a difficult problem, conventional operations against a weaker military adversary, to a far more complex problem, pacification and stabilization of a chaotic country of

${ }^{34}$ Jay Garner, “Iraq Revisited,” in Turning Victory Into Success, Military Operations After the Campaign, ed. Dr. Lieutenant Colonel Brian M. De Toy (Fort Leavenworth, KS: Combat Studies Institute Press, 2004), 265.

\footnotetext{
${ }^{35}$ Ibid, 265.

${ }^{36}$ Jeffrey Record, Beating Goliath, Why Insurgencies Win (Washington DC: Potomac Books, 2009), 79.

${ }^{37}$ Keegan, 207.

${ }^{38}$ David Kilcullen, The Accidental Guerilla (New York, NY: Oxford University Press, 2009), 152.
} 
nearly thirty million. In much the way Ashby’s Law dictates that an organization must become as complex as the complexity required, US forces were then required to orient to the relative complexity required for a population-centric counterinsurgency effort.

The approach US forces took, often called “the surge,” involved numerous changes that increased their complexity to match the operational environment in a number of ways. The multi-faceted approach included a surge of 30,000 US troops into Iraq and a rebasing of a large portion of US troops from forward operating bases into the population, while employing new doctrine and tactics to enhance their effectiveness. In addition, US forces increased the coalition's ability to penetrate the complexity of Iraqi society by enlisting an Iraqi proxy army of 60,000 men to police local areas, and aligning with a Sunni led uprising against Al Qaeda called the “Anbar Awakening.”39 The complexity required for populationcentric counterinsurgency was characterized by Record:

"Most MOOTW (Military operations other than war), however, including counterinsurgency, are inherently manpower intensive and rely heavily on special skills- human intelligence, civil affairs, police, public health, foreign language, foreign force training, psychological warfare-that are secondary, even marginal, to the prosecution of conventional warfare. Forces capable of achieving swift conventional military victory thus may be quantitatively and qualitatively unsuited for post-victory tasks of a the kind the United States has encountered in Iraq." 40

Within months, the results of the new strategy were evident, the country began to settle down, and the tide of the war turned in favor of US short-term objectives. Although the long-term fate of Iraq still remains to be seen, the adaptation of US forces from conventional operations to more complex operations, along with the use of a complex Iraqi organic capability to affect the population, demonstrates the organizational change required when problems become more complex.

Israel chose to escalate the conflict with Hezbollah into a full-blown war on July $12^{\text {th }}$, 2006 when two of its soldiers were abducted at a border point with Southern Lebanon. What began was a thirty-three

\footnotetext{
${ }^{39}$ Michael Duffy, "The Surge at Year One," Time Magazine (January 31, 2008)

http://www.time.com/time/magazine/article/0,9171,1708843-2,00.html (accessed June 15, 2010).

${ }^{40}$ Record, 111.
} 
day campaign in which the Israeli Air Force (IAF) flew some 15,500 sorties and attacked over 7,000 targets, while the Israeli Army fired some 100,000 artillery rounds and committed at least 15,000 troops into Southern Lebanon. During the operation, Hezbollah fired over 3,700 rockets into Israel killing fortytwo civilians and wounding 4,262. ${ }^{41}$ By attacking infrastructure targets throughout Lebanon, and directly engaging Hezbollah rocket forces, primarily with airpower, it was believed that the IDF could hand Hezbollah forces a major defeat while ending the launching of rockets into Israel from Southern Lebanon. On both counts, the IDF failed miserably. ${ }^{42}$

Unfortunately for the IDF, it did not apply the correct forces for the problem it was trying to manage. The IAF was tasked with destroying Hezbollah rocket units dispersed in Southern Lebanon without a large ground force to augment its operations. Hezbollah anticipated this and operated in distributed cells throughout Southern Lebanon. Initially, the IAF had some success in slowing the rocket attacks, especially the long-range rockets, but had little to no success in stopping the rocket launches as a whole. Not until after two weeks of ineffective air operations did the IDF begin a ground campaign into Southern Lebanon. The initial part of the ground campaign was very small-scale and proved to be ineffective. By the time the IDF began a large-scale ground operation, it was twenty-nine days into the war.

This provides a good learning point for understanding military operations through the tradeoff of complicated and complex problems. Hezbollah correctly anticipated that the IDF would use airpower to go after their rocket forces; therefore, they employed their rocket forces in distributed cells in difficult terrain to ramp up the level of complexity the IAF was forced to deal with. IDF Major General Ido Nehushtan recognized the inability of airpower to match the needed complexity and stated that without a major land campaign, the IDF could not stop the rocket attacks. He noted, "Without a major land

${ }^{41}$ Matt M. Matthews, We Were Caught Unprepared, The 2006 Hezbollah-Israeli War (Fort Leavenworth, KS: Long War Series Occasional Paper 26, Combat Studies Institute Press, 2006), 61.

${ }^{42}$ Anthony H. Cordesman, Preliminary Lesson of the Israel-Hezbollah War (Washington DC: Center for Strategic and International Studies, 2006), 3. 
operation, we cannot remove the rocket threat. If the government does not approve a large pre-planned ground offensive, we should tell them they must stop the campaign now."43 His comments are a critique that airpower in this case could not stop the Hezbollah rocket units because it was not capable of matching the complexity they presented. What the IDF should have done is tailor a force that could match the complexity of the problem it was assigned to manage. The only force that was capable of doing this was a large-scale ground invasion of Southern Lebanon. The IDF realized this, but not until twenty-nine days into a thirty-three day operation. Because of this, the IDF operation in Southern Lebanon was a failure.

In the end, both operations in Iraq and Southern Lebanon provide examples that emphasize the importance of understanding the tradeoff between complicated and complex problems. Organizations that orient more towards complicated problems can be more efficient, but struggle with complexity. US forces in Iraq did well through the "shock and awe campaign," because they were oriented to an enemy they knew very well that fought in a very predictable way. This predictability played in to the strengths of the US military. Once operations became more complex after de-Baathification, US forces struggled with managing the situation because they were not oriented for complex operations. Not until they increased the complexity of their forces in accordance the Law of Requisite Variety to match the complexity of the Iraqi environment were they able to manage the insurgency.

The IDF example is a much more specific one. The IDF struggled with getting its airpower to manage the complex problem of distributed Hezbollah rocket units, not only because airpower is not suited for the operation, but also because the IDF did not send ground forces into Southern Lebanon in an appreciable way until the war was nearly over. The inability to anticipate the tradeoff between complicated and complex problems caused the United States in Iraq to nearly lose control of the country it invaded, and the IDF to suffer a defeat by the hands of Hezbollah.

\footnotetext{
${ }^{43}$ Matthews, 48.
} 


\section{COMPLEXITY AT LARGE-SCALE AND COMPLEXITY AT FINE-SCALE}

"The continued dominance of America's Armed Forces in large-scale force-on-force warfare provides powerful incentives for adversaries to employ methods designed to offset our strengths." 44

Quadrennial Defense Review 2010

It is no coincidence that the US Army’s Counterinsurgency (COIN) Field Manual (FM) 3-24 begins by identifying the organizational tradeoff between complexity at large versus fine-scale. The FM states that it is troublesome for military forces attempting to do COIN when they "conduct large-scale operations as the norm." 45 This tradeoff is much like the tradeoff of complicated versus complex problems, but as that tradeoff is about linearity and predictability, the tradeoff of large-scale versus finescale has to do with coordinated action of respective parts or lack thereof. Large-scale implies more coordination to produce large-scale effects, while fine-scale implies less coordination for distributed operations with many effects simultaneously. Understanding this tradeoff can help the military practitioner see asymmetric weakness and better learn, anticipate and adapt to military problems.

The definition of scale by Yaneer Bar-Yam is, "the number of parts of a system that act together in a strictly coordinated way." ${ }^{46}$ Large-scale is not necessarily big; rather it is the specialization in coordinating the parts of an organization to mass large-scale effects. Fine-scale involves parts distributed in ways to amass many different effects simultaneously. Fine-scale specialization is distributed; uncoordinated operations penetrate into fine-scale complexity at the expense of massing large-scale effects. Modern militaries attempt to attain a balance between both types of specialization for the wide

\footnotetext{
${ }^{44}$ Department of Defense, The 2010 Quadrennial Defense Review: Refocusing Priorities (Washington DC: 2010), 7.

${ }^{45}$ Headquarters Department of the Army, FM 3-24; Counterinsurgency (Washington, DC: U.S. Department of the Army, 2006), 1-29.

46 Yaneer Bar-Yam, Multi-scale Representations Phase II, (Rome, NY: Ft. Belvoir Defense Technical Information Center, 2004), 100, http://www.dtic.mil/cgibin/GetTRDoc?AD=ADA423165\&Location=U2\&doc=GetTRDoc.pdf (accessed 27 Aug 2010).
} 
range of operations anticipated. Still many organizations orient more towards one or the other.

Organizations can choose to re-orient from large-scale to fine-scale, or vice-versa, but this can be a difficult challenge that involves resources, time and often cultural changes in the organization.

Although they may seem the same, the tradeoff between orienting for complexity between largescale and fine-scale is not the same as the tradeoff between complicated and complex problems. The difference between complicated and complex problems is primarily based on predictability or linearity or lack thereof, while problems of scale are based on coordinating the parts of an organization to either maximize effects, or maximize penetration into fine-scale complexity. A problem can be complicated and large-scale but not necessarily so. Both complicated and large-scale problems are best suited by hierarchical command and control systems, but large-scale problems are not necessarily predictable and linear; they simply require a large-scale solution. According to Yaneer Bar-Yam,

"The significance of complexity is most readily apparent, however, when we consider the capabilities of small-scale (fine-scale) forces against large-scale conventional forces in a high complexity terrain. Heavy military equipment (ships and tanks) that provide an advantage in simple terrains (ocean, desert and plains) are often a liability in mountainous, jungle, littoral or urban terrains. Massing forces for offensive and defensive advantage in simple conflicts is counter indicated in complex conflicts where dispersal provides an advantage. These observations are apparent when considering the capabilities of guerrillas against massed forces in a jungle, tanks in the mountains and ships in a port.”,

A good example of the difference between complexity at a large-scale versus fine-scale can be found in Mao Zedong's theory of protracted war. In Mao’s theory, insurgents begin operations in the finescale complexity of the population where the government cannot see, because the government is oriented towards large-scale operations. This is a "blind spot" for the government and becomes the primary breeding ground for the budding insurgency. This is called Phase 1, or strategic defensive. In this phase, the "government has a stronger correlation of forces and insurgents must concentrate on survival and building support.” ${ }^{48}$ Insurgents build this support in institutions that are very difficult for governmental

\footnotetext{
${ }^{47}$ Bar-Yam, Complexity of Military Conflict: 24.

${ }^{48}$ Headquarters Department of the Army, FM 3-24; Counterinsurgency (Washington, DC: U.S. Department
} of the Army, 2006), 1-6. 
control such as tribes, town and families. As the support for the insurgency spreads, eventually the insurgency starts to collate into cells that can challenge governmental control. This is what Mao describes as Phase 2, or strategic stalemate. This happens when, “force correlations approach equilibrium and guerilla warfare becomes the most important activity." 49 After this, insurgents continue to build their ability to challenge the government in scale eventually to the point where they can challenge the government directly. This is called Phase 3, or strategic counteroffensive. This happens when, "insurgents have superior strength and military forces move to conventional operations to destroy the government's military capability. ${ }^{50}$ From Phase 1 to Phase 3, the insurgency gains the ability to coordinate disparate parts until it eventually can coordinate enough parts to threaten the government directly.

T.E. Lawrence described orientation specifically for fine-scale complexity in a concept he called “maximum articulation.” Maximum articulation is the distributed operation of an insurgency at the most fine-scale level possible. For him it was characterized by distributed operations to the point where the small units required no lines of communication or "labor troops," a term he used to describe logistical support. Lawrence continued: "The efficiency of each man was his personal efficiency. We thought that in our condition of warfare the sum yielded by single men would be at least equal to the product of a compound system, and it was certainly easier to adjust to tribal life and manners, given elasticity and understanding on the part of the commanding officers." 51

The tradeoff of complexity across scale does not imply that large-scale warfare is less complex than fine-scale warfare. Rather the tradeoff indicates that an organization cannot do it all and specialization in one area limits specialization in other areas. As stated previously, the Law of Requisite Variety suggests that for a system to control a complex environment, it must become as complex as the environment around it. This applies at a certain level of scale as well, but as the scale of effects required

\footnotetext{
${ }^{49}$ Ibid, 1-6.

${ }^{50}$ Ibid, 1-6.

${ }^{51}$ Alex J. Ryan, Military Applications of Complex Systems, 749.
} 
becomes larger, the organization's ability to penetrate into fine-scale complexity decreases. Bar-Yam describes what penetrating into fine-scale complexity requires:

"The force organization, training, preparation and equipment should enable highly independent application of multiple forces whose offensive and defensive scale sufficiently exceeds the scale of the individual challenges to be met. Compared to traditional war fighting, the key to success in such complex warfare contexts is the capability of small units to act independently. The emphasis must be on highly autonomous and independently capable forces with relatively weak coordination, rather than large-scale coherence of forces. Small unit independence increases the number of actions that can be taken, i.e. complexity. This is manifest in the special force operations." 52

However, just as an organization orients away from complicated and more towards complex problems, as an organization orients away from large-scale and more towards fine-scale complexity, it becomes less capable of conducting large-scale operations. Bar-Yam comments, "Since complexity increases rapidly as the independence of units at the desired scale of action increases, but larger scale actions are possible only as the coordination between such units increases, there is an inherent tradeoff between the complexity of action at one scale and (complexity) of larger scale actions.”53

\section{Iraq and Southern Lebanon}

US forces in Iraq in 2003 specialized in large-scale military operations. This proved to be fortunate when the enemy was an Iraqi military designed to fight in force on force large-scale warfare. In just the same way as highlighted in the tradeoff between complicated and complex problems, however, US forces' orientation for large-scale operations became a problem when fine-scale complexity was required in population-centric counterinsurgency operations. Not until US forces adapted with a new counterinsurgency campaign and oriented towards fine-scale complexity into the population were they able to turn the tide of the war. The IDF ground forces in Southern Lebanon struggled because they were overly oriented for fine-scale operations after numerous years conducting fine-scale population-centric operations in Palestine. Once the IDF decided to launch a ground campaign, it was not able to conduct

\footnotetext{
${ }^{52}$ Bar-Yam, Complexity of Military Conflict, 20.

${ }^{53}$ Ibid, 25.
} 
combined arms warfare or mass firepower quickly enough to match that large-scale opposition presented by Hezbollah.

In the figure below, a comparison of military organizations is shown across an axis of scale. On the left are organizations that are more oriented towards fine-scale operations. In much the way as described in Mao’s Level 1, these organizations typically are not well trained in coordinated operations, but because they are small, they can blend in with populations. They utilize small-scale weapons, and have highly distributed command and control networks. These organizations also demonstrate T.E. Lawrence's concept of “maximum articulation," in that they can become highly independent. On the far right of the figure are organizations that are oriented towards large-scale operations. These organizations specialize in coordinated operations, are able to utilize weapons of large-scale, and possess more centralized command and control.. The position along this scale is not a fixed one as organizations can organize, train and equip to move their position along the axis.

Because of the tradeoff of complexity across scale, if an organization is organized on one side of the axis, it is poorly organized to function on the other side of the axis. Some organizations attempt to have capabilities across the axis, but this is done at great expense. The US military is an example of this. Its conventional forces are oriented on the right side of the axis, while its special operations forces are oriented more toward the left. Still, US special operations forces are not large enough to manage large fine-scale problems. 




Figure 1: A Comparison of Military Organizations Along An Axis of Scale ${ }^{54}$

At the beginning of the war in Iraq in 2003, US forces were oriented mostly on the far right side of the axis at the expense of functioning effectively on the left side. US special forces had some ability to manage the left side of the axis, but were not large enough in number to effectively manage the fine-scale problem in Iraq. After de-Baathification, US forces as a whole changed their orientation to move left across the axis. This occurred when US forces adapted to the fine-scale complexity of population-centric counterinsurgency operations. In order to penetrate into the fine-scale complexity of the population and the insurgency, US forces confronted the problem with distributed operations, decentralized command and control, and small formations. This enabled them to confront forces such as Al Qaeda and the Sunni uprising. As US forces oriented for operations on the left side of the axis, however, they became less able to conduct coordinated operations on the right. Because of the tradeoff of complexity across scale, if an

${ }^{54}$ David E. Johnson, Military Capabilities for Hybrid War, Insights from the Israel Defense Forces in Lebanon and Gaza (Santa Monica, CA: RAND, 2010), 36. 
organization such as the US military in Iraq focuses on specializing for fine-scale operations it does so at the cost of specializing in large-scale operations.

John Nagl, in his book Learning to Eat Soup With a Knife, suggests that this shift is very difficult for military organizations, especially for the US military because of its historical roots in large-scale state on state warfare: "the demands of conventional and unconventional warfare differ so greatly that in extremis it may be very difficult, if not impossible for an organization optimized for one to adapt to the other." ${ }^{55}$ Historically, US forces have been oriented for large-scale operations against major nation states such as the Soviet Union. This orientation has been chosen at great expense in anticipation for a specific problem. Other countries orient their militaries for other reasons. One example Nagl describes is the military of Britain. He asserts, “The American Army’s role from its very origins was the eradication of threats to national survival, in contrast to the British Army’s history as an instrument of limited war, designed to achieve limited goals at limited cost." ${ }^{56}$ Eliot Cohen adds that large-scale operations are part of the American way of warfare: "the two dominant characteristics of American strategic culture are: The preference for massing a large number of men and machines and the predilection for direct and violent assault." 57

For the IDF, once it began operations into Southern Lebanon, its ground forces found themselves unprepared for coordinated action against Hezbollah. After six years of operations in Palestine, the IDF had adapted to specialize in operations against the Palestine Liberation Organization. Hezbollah, as can be seen in Figure 1, possessed the ability to muster moderate sized formations and utilize standoff weapons against the IDF. According to the Winograd report, this capability took the IDF by surprise: “The IDF

\footnotetext{
${ }^{55}$ Nigel Aylwin-Foster, “Changing the Army for Counterinsurgency Operations,” Military Review, November, 2005, 10, http://findarticles.com/p/articles/mi_m0PBZ/is_6_85/ai_n27865529/?tag=content;col1 (accessed September 10, 2010).

56 Ibid, 10.

${ }^{57}$ Ibid, 10.
} 
was not ready for this war...since Israel did not intend to initiate a war, the conclusion was that the main challenge facing the land forces would be low intensity asymmetrical conflicts.”58

Once the IDF introduced ground forces into the conflict, this lack of conventional skill became clear as it made mistake after mistake in conventional operations against Hezbollah’s coordinated operations. IDF ground forces were oriented for fine-scale operations, while Hezbollah was oriented for operations in between fine-scale and large-scale. This created an advantage for Hezbollah in force on force warfare. One example of this advantage occurred in a fight at Wadi-al Saluki, where IDF tank commanders "failed to use their smokescreen systems, lacked indirect fire skills and possessed a total absence of combined arms proficiency." ${ }^{59}$ As Anthony Cordesman stated,

"One of the key deficiencies was that the Israeli Army, highly conditioned by its LIC experience, was initially confounded by an enemy that presented a high-intensity challenge that required joint combined arms fire and maneuver and a combat mindset different from that of Palestinian terrorists, even though Hezbollah did not have large formations. One IDF Israeli observer noted "Prior to the war most of the regular forces were engaged in combating Palestinian terror. When they were transferred to Lebanon, they were unfit to conduct combined forces battles integrating infantry, armored, engineering, artillery forces, and other support forces." 60

In addition to this, Hezbollah forces waged an effective campaign against IDF conventional forces using modern weaponry and swarm tactics. Of the 114 IDF personnel killed during the war, 30 were tank crewman. Also, of the 400 tanks involved in fighting in Southern Lebanon, 48 were hit, 40 were damaged, and 20 penetrated. Matt Matthews added: "Hezbollah also deserves high marks for its innovative use of sophisticated ambushes and the clever use of both direct and indirect fires." ${ }^{\text {,1 }}$ According to Cordesman, “The (Hezbollah) fighters are well trained, they were prepared, and like the Iranians, they have solid, long-range planning and operational staff in place. Their C4 is very sophisticated. They have an impressive technology set piece (they purchased a lot from the Russians through cutouts) and have

\footnotetext{
58 Ibid, 10.

${ }^{59}$ Matthews, 63.

${ }^{60}$ Cordesman, 13.

${ }^{61}$ Matthews, 64.
} 
excellent satellite capabilities. ${ }^{62}$ These all provide examples of an organization that is capable of

conducting scaled operations above that which its adversary was prepared for and was able to exploit that advantage. Matthews adds:

"The Hezbollah fighters assigned to protect the rockets were armed and equipped with a massive array of sophisticated weaponry. Its fighters had trained extensively to integrate mortars and rockets into this lethal mix by presighting suspected Israeli avenues of approach and training forward observers in proper indirect fire procedures. Mines and IEDs were expertly placed throughout the southern defensive sector in order to stop Israeli mechanized forces and enable Hezbollah to mass both direct and indirect fires. A sturdy and technically advanced underground command and control (C2) system was designed to help with the expedient delivery of orders to the front. Evidence also suggests that Hezbollah's military commanders planned to keep firm operational control over their rocket units, while giving more tactical leeway to their ground troops" 63

The tradeoff of complexity across scale provides an excellent lesson for the military practitioner wanting to learn, anticipate or adapt to military problems. US forces possessed the ability to conduct large-scale operations against the Iraqi military, but faltered when fine-scale operations were required for the counterinsurgency campaign. This misorientation nearly cost the United States control of Iraq. The IDF after six years of operations in Palestine fought Hezbollah with a ground force that was still oriented for the level of scale of the Palestinian problem. Since Hezbollah was able to overwhelm the IDF in conventional operations by employing a larger scale in its defense than the IDF was able to bring, it dealt the IDF a conventional defeat.

\footnotetext{
${ }^{62}$ Cordesman, 32.

${ }^{63}$ Matthews, 18.
} 


\section{EXPLORATION AND EXPLOITATION}

"The new principles of war are no longer 'using armed force to compel the enemy to submit to one's will,' but rather are 'using all means, including armed forces or non-armed force, military and nonmilitary, and lethal and non-lethal means to compel the enemy to accept one's interest." ${ }^{4}$

Liang Qiao and Xiangsui Wang, Unrestricted Warfare

The book Unrestricted Warfare highlights an excellent example of the exploration of military theory and doctrine. Organizations make decisions on the tradeoff between exploiting certainties versus exploring new possibilities. This is certainly true for military organizations. War is a constant struggle between adversaries that explore new opportunities for advantage and exploit advantages they already possess. Much like complicated versus complex problems and complexity across scale, exploration of new solutions and exploitation of known solutions involve an important tradeoff worth understanding to help military practitioners better learn, anticipate and adapt to military problems.

Exploration is the process of looking for new ways and means through which to conduct warfare, or new ways and means with which an enemy could conduct warfare. Exploration includes things such as search, variation, risk taking, experimentation, play, flexibility, discovery, and innovation. ${ }^{65}$ These things involve creative efforts at innovation to gain advantage in military conflict. For the military organization, to not explore these things may lead to asymmetric weakness that an enemy can exploit at will. James March explains that exploration may be essential, but the results from exploration can be difficult to see or measure:

"Compared to returns from exploitation, returns from exploration are systematically less certain, more remote in time, and organizationally more distant from the locus of action and adaptation. The essence of exploration is experimentation with new alternatives. Its returns are uncertain, distant, and often negative. Thus, the distance in time and space between the locus of learning and the locus for the realization of

64 Qiao Liang, Xiangsui Wang, Unrestricted Warfare (Beijing: PLA Literature and Arts Publishing House, February 1999), http://www.terrorism.com/documents/unrestricted.pdf (accessed 12 August, 2010).

65 James March, Exploration and Exploitation in Organizational Learning (Stanford, CA: Graduate School of Business, Stanford University, 1991), 71. 
returns is generally greater in the case of exploration than in the case of exploitation, as is the uncertainty" 66

Exploitation includes such things as refinement, choice, production, efficiency, selection, implementation, and execution. ${ }^{67}$ This process provides the organization the ability to make best use of known practices. According to March, "the essence of exploitation is the refinement and extension of existing competences, technologies, and paradigms. Its returns are positive, proximate, and predictable.”“68 Therefore, it becomes attractive to organizations to focus only on exploitation because the returns are often easier to see. John Holland adds, “Although exploitation yields more certain and immediate returns, it makes the discovery of truly novel situations unlikely and can lead to obsolescence in the long run.”, 99 This can become a problem for military organizations over time. Holland notes, "Deciding to what degree the present should be mortgaged for the future is a classic problem for all systems that adapt and learn.,70 Too much of either exploration or exploitation can lead to serious problems. In the case of too much exploration, a concept called eternal boiling can take place in which objective truths can be hard to come by. According to Robert Axelrod and David Cohen, eternal boiling occurs when the level of mutation, temperature, or noise is so high that the system remains permanently disorderly. Any potentially valuable structures are broken apart before they can be effectively put to use. ${ }^{71}$ When there is too much exploitation happens a concept called premature convergence in which there exists too little variability. Premature convergence occurs when needed variability is lost too quickly. This can occur

${ }^{66}$ Ibid, 75.

${ }^{67}$ Ibid, 71.

${ }^{68}$ Ibid, 85.

${ }^{69}$ John H. Holland, “Genetic Algorithms,” Scientific American, May, 2005, 66-72.

${ }^{70}$ John H. Holland, Adaptation in Natural and Artificial Systems, (Ann Arbor, Michigan: University of Michigan Press, 1975).

${ }^{71}$ Robert Axelrod and Michael Cohen, Harnessing Complexity (New York, NY: Simon and Schuster, 2000), 44. 
when very speedy imitation of an initial success cuts off future system improvements. ${ }^{72}$ Success in this case can ultimately lead to failure. According to M. J. Benner and M. Tushman, the tensions between short-term and long-term gain affect the tradeoff between exploration and exploitation. "While exploration can enable the discovery of profoundly novel solutions, it also typically causes a degradation of performance in the short run because searches for novel solutions usually fail. Not surprisingly then, a number of studies have shown that the pursuit of greater efficiency will often drive individuals or organizations to overemphasize exploitation at the expense of exploration.”73 B. Levitt and James March add, "In an organizational context exploitation yields more certain and immediate results, exploration creates and preserves the requisite variety of knowledge necessary for the organization to sustain its learning in the long term."74

\section{Iraq and Southern Lebanon}

In Iraq, US forces were able to exploit advantage against the Iraqi army, but were unable to exploit advantage soon after de-Baathification. This happened because they had not explored the requirements to re-orient to population-centric counterinsurgency operations of the complexity and scale encountered. Eventually, US forces were able to explore the new requirements for the counterinsurgency campaign as a whole, and were able to adapt to the required problem. In the war in Southern Lebanon, it was Hezbollah that did a better job of exploring new possibilities. With the help of Iran, Syria and North Korea, Hezbollah developed into a very capable fighting force able to rapidly adapt its rocket units fast

\section{${ }^{72}$ Ibid, 44.}

${ }^{73}$ M.J. Benner, M. Tushman, "Exploitation, Exploration and Process Management: The Productivity Dilemma Revisited,” (Boston, MA: Harvard University, September 17, 2001), 12, http://www.gepeq.dep.ufscar.br/arquivos/Artigo-GerenciadeProcessos-InovacaoExploitation.pdf (accessed June 30, 2010).

${ }^{74}$ Barbara Levitt and James G. March, “Organizational Learning,” Annual Review of Sociology (August 14, 1998), 319-320, http://www.knowandpol.eu/fileadmin/KaP/content/Literaturedownloablepapers/IJKL/Levitt_and_March_1988_.pdf (accessed June 23, 2010). 
enough to evade Israeli Air Force attacks, while mounting a lethal conventional defense of Israeli ground force incursions into Southern Lebanon.

For the US, once de-Baathification occurred, it adapted and explored new possibilities for conducting a successful population-centric counterinsurgency campaign. One way in which US Forces explored new possibilities was in self-organization and adaptation at the lower echelons. According to Nagl; "Tank battalions, which just weeks previously had been required to execute missions no more complicated than Attack and Defend, learned how to conduct Area Denial Operations and Special Forcesstyle raids even as their battalion leadership conducted political negotiations and trained and equipped Iraqi police and National Guard forces.” ${ }^{, 5}$ Doctrinally, the US Army developed the Field Manual 3-24, which detailed doctrinal guidance on conducting successful counterinsurgency operations. Intellectually, numerous articles entered into the military discourse through publications such as Military Review and Joint Forces Quarterly.

Another attempt at exploration into new ways in which to conduct population-centric counterinsurgency operations was in the Commander's Emergency Response Program (CERP), which gave field commanders funds that they could use at their disposal for local projects in Iraqi communities. Nagl adds, CERP, “provides field commanders funds to perform essential projects, wins hearts and minds twice over- once by repairing infrastructure, and again by employing local citizens who are otherwise ready recruits for the insurgents. CERP is helping with the painstaking process of building relationships with the Iraqi people.”76

Distributed operations were another form of exploration that US forces pursued to conduct effective operations in Iraq. These distributed operations pushed small units of ground forces into the

\footnotetext{
${ }^{75}$ John A. Nagl, Learning to Eat Soup With a Knife (Chicago, IL: University of Chicago Press, 2005), xv. ${ }^{76}$ Ibid, xiii.
} 
streets and neighborhoods of the Iraqi population. By their location and proximity, these units were able to penetrate better into the fine-scale complexity of Iraq. Nagl added,

"The United States Army has taken remarkable strides to adapt to the demands of counterinsurgency in Iraq in a process called the Modular Army. Stepping away from the 15,000-soldier division as the center of gravity of the army, this program creates more nimble 4000-soldier Units of Action able to operate independently over a wide area. The army is also taking steps to increase the numbers of soldiers with much needed special skills including the counterintelligence and civil affairs soldiers that Task Force 1-34 Armor put to such good use in Khalidiyah. Programs to recruit additional Arabic speakers are underway in both the Active Army and National Guard, adding another essential weapon to the counterinsurgency capability of the nation."77

In Southern Lebanon, it was Hezbollah that explored new ways in which to conduct operations against the IDF. For the six years leading up to the conflict with the IDF, Hezbollah explored numerous possibilities it could exploit. It did this with great success and caught the IDF off guard with its asymmetric capabilities. According to Matt Matthews, "From 2000 to 2006, Hezbollah successfully embraced a new doctrine, transforming itself from a predominantly guerrilla force into a formidable quasi-conventional fighting force. Hezbollah correctly ascertained the manner in which the IDF would fight the war and prepared its resources and command and control systems to effectively withstand an EBO campaign.”78

The IDF incorrectly assessed that all it needed to do to defeat Hezbollah was to exploit its advantage in airpower and fine-scale ground operations. This proved an incorrect assumption and one that highlights what can happen when a military force fails to explore new potentials and only focuses on perceived opportunities for exploitation. The IDF used previous operations to justify the reliance on airpower to break the will of Hezbollah forces. This proved to be a huge mistake for the IDF. According to David E. Johnson, “The 1999 war in Kosovo, Operation Enduring Freedom in Afghanistan, and Operation Iraqi Freedom (OIF) spurred a belief in the Israeli defense establishment that standoff attack by

\footnotetext{
${ }^{77}$ Ibid, XV.

${ }^{78}$ Matthews, 64.
} 
fires (principally by air power) was an effective means to affect the will of the adversary and determine conflict outcomes. ${ }^{79}$

The tradeoff between exploiting certainties and exploring new possibilities in military operations is a critical concept to understand if a military practitioner wishes to learn, anticipate and adapt to military problems. As depicted in the example of the United States in Iraq, US forces exploited a known advantage over an enemy leading to an historic victory. Because US forces were so focused on exploiting conventional advantage, however, they did not allocate the resources needed towards exploring counterinsurgency until an insurgency had already begun. This failed understanding of the tradeoff between exploration and exploitation almost cost the United States control of the Iraqi population. In Southern Lebanon, Hezbollah explored new ways and means in which to deal the IDF a defeat while the IDF failed to do the same. The IDF adapted its ground forces in the previous six years on becoming a police force in Palestine. Because it did this, its conventional capabilities began to erode. When it focused on exploiting its ability to conduct operations in Palestine, but failed to explore conventional capabilities such as combined arms maneuver, the IDF became vulnerable to a conventional enemy. Hezbollah over the previous six years had vigorously explored conventional capabilities and exploited its advantage over the IDF ground forces in combat. Both of these examples provide a learning opportunity for military practitioners. Organizations cannot only exploit perceived advantages and without exploring new possibilities. If they do so, they risk defeat.

79 Johnson, 2. 


\section{CONCLUSION}

"Thus it is said that one who knows the enemy and knows himself will not be endangered in a hundred engagements. One who does not know the enemy but knows himself will sometimes be victorious, sometimes meet with defeat. One who knows neither the enemy or himself will invariably be defeated in every engagement." 80

Sun-Tzu, The Art of War

This monograph is about knowing the enemy, as well as knowing yourself. Knowing the enemy includes understanding the types of problems that an enemy and situation can present. Knowing yourself includes understanding the tradeoffs that affect how you anticipate and adapt to those types of problems. The tradeoffs presented in this monograph provide additional conceptual tools to help the military practitioner better learn, anticipate and adapt to military problems.

The United States in Iraq in 2003 performed well in conventional operations, but faltered when operations shifted to controlling the Iraqi population. This was a result of failing to orient quickly to finescale complexity in the Iraqi population after de-Baathification. The United States was unable to orient quickly because it had not explored population-centric counterinsurgency operations until after the insurgency had begun. In Southern Lebanon in 2006, Hezbollah rocket units effectively avoided destruction at the hand of the IAF, while Hezbollah ground forces embarrassed the IDF's ground forces in conventional operations. Hezbollah had in the years leading up to the conflict explored ways in which to deny IAF effectiveness while directly challenging IDF ground forces by overwhelming them in largescale coordinated operations.

These two cases provide informative examples of failure to learn, anticipate and adapt to military problems. Fortunately for the United States, it was allowed the time and political capital to adapt to the problems on the ground after the effects of de-Baathification. The IDF was not so lucky as their war was cut short and ended in defeat. As many consider these two armed forces to be the most competent and

\footnotetext{
${ }^{80}$ Sun Tzu, The Art of War (Oxford, Westview Press, 1994), 179.
} 
proficient forces in the world, it is clear that these kinds of mistakes could happen again. What can military practitioners learn from these examples?

The first thing military practitioners should learn is that it should be expected that operations will occur that challenge a military’s orientation. As described by President Barack Obama in the 2010 National Security Strategy, we must be prepared for a very broad spectrum of possibilities: "Our military must maintain its conventional superiority and, as long as nuclear weapons exist, our nuclear deterrent capability, while continuing to enhance its capacity to defeat asymmetric threats, preserve access to the global commons, and strengthen partners." ${ }^{\prime 11}$ To cover as wide a spectrum as possible will require deep theoretical understanding by military practitioners with a broad knowledge of problems and tools that are useful in managing those problems.

The second thing military practitioners should learn is that every choice involves a tradeoff and no military campaign fits neatly into an understandable conceptual model. The saying, "all models are wrong, some are useful,” rings very true when trying to simplify the myriad of problems of a military campaign between adapting enemies. That is why the military practitioner should add to his conceptual toolkit many ways in which to learn, anticipate and adapt to military problems.

The conceptual tradeoffs of complicated versus complex, complexity across scale, and exploration versus exploitation provide additional vantage points from which to think about military problems. They provide a cost benefit look at how well organizations, more specifically military organizations, are suited when confronting military problems. More specifically, how an organization orients to a problem is determined at the cost of orienting successfully towards other problems. There are no perfect solutions to how an organization orients itself for problems, only some solutions that are better than others.

\footnotetext{
${ }^{81}$ United States President Barack Obama, National Security Strategy (Washington, DC: White House, 2010), 14.
} 
According to Clausewitz, “a working theory is an essential basis for criticism. Without such a theory it is generally impossible for criticism to reach that point at which it becomes truly instructive.” ${ }^{2}$ These tradeoffs, which come from the evolving theory of complexity, provide additional concepts in which to leverage practical solutions and in the end better military results. As Carl H. Builder notes, "How the services perceive the next major war they must fight is an important determinate of the types of forces they acquire, the doctrine they develop, and the training they follow for the use of those forces in combat." ${ }^{83}$ Michael Howard says it even better: "In structuring and preparing an Army for war you can be clear that you will not get it precisely right, but the important thing to ensure is that it is not too far wrong, so that you can put it right quickly." ${ }^{84}$ We must leverage our conceptual toolkit to be instructive enough so that in the next war, we prevail. Understanding the three tradeoffs described in this monograph can help to do just that.

\footnotetext{
${ }^{82}$ Sun Tzu, 157.
}

${ }^{83}$ Carl H. Builder, The Masks of War: American Military Styles in Strategy and Analysis (Baltimore, MD: John Hopkins University Press, 1989), 128.

${ }^{84}$ General Sir Charles Guthrie, "The British Army at the Turn of the Century,” RUSI Journal 141/3 (June 1996), 6. The original citation is Michael Howard, "Military Science in the Age of Peace," RUSI Journal (March 1974), 3-4. 


\section{BIBLIOGRAPHY}

Axelrod, Robert and Michael Cohen. Harnessing Complexity. New York, NY: Simon and Schuster, 2000.

Aylwin-Foster, Nigel. “Changing the Army for Counterinsurgency Operations.” Military Review, November, 2005.

http://findarticles.com/p/articles/mi_m0PBZ/is_6_85/ai_n27865529/?tag=content;col1 (accessed September 10, 2010).

Bar-Yam, Yaneer. Complexity of Military Conflict: Multiscale Complex Systems Analysis of Littoral Warfare. New England Complex Systems Institute, 2003.

Bar-Yam, Yaneer. Multi-scale Representations Phase II. Rome, NY: Ft. Belvoir Defense Technical Information Center, 2004. http://www.dtic.mil/cgibin/GetTRDoc?AD=ADA423165\&Location=U2\&doc=GetTRDoc.pdf (accessed 27 Aug 2010).

Bar-Yam, Yaneer. Making Things Work: Solving Complex Problems in a Complex World. Cambridge, MA: NECSI, Knowledge Press, 2004.

Benner, M.J. and M. Tushman. "Exploitation, Exploration and Process Management: The Productivity Dilemma Revisited.” Boston, MA: Harvard University, September 17, 2001. http://www.gepeq.dep.ufscar.br/arquivos/Artigo-GerenciadeProcessos-InovacaoExploitation.pdf (accessed 30 June, 2010).

Beyerchen, Alan. "Clausewitz, Nonlinearity, and the Importance of Imagery.” in Complexity, Global Politics, and National Security. ed. David S. Alberts and Thomas Czerwinski. Washington DC: National Defense University, 1997. http://www.au.af.mil/au/awc/awcgate/ndu/complexity/comch07.html (Accessed 15 April, 2010).

Builder, Carl H. The Masks of War: American Military Styles in Strategy and Analysis. Baltimore, MD: John Hopkins University Press, 1989.

Cohen, Eliot A. and John Gooch. Military Misfortunes: The Anatomy of Failure in War. New York; London: Free Press; Collier Macmillan. 1990.

Cordesman, Anthony H. Preliminary Lesson of the Israel-Hezbollah War. Washington DC: Center for Strategic and International Studies, 2006.

Clausewitz, Carl Von. On War. Princeton, NJ: Princeton University Press, 1976.

Davis, Paul K. Aggregation, Disaggregation, and the 3:1 Rules in Ground Combat. Santa Monica, CA: RAND, 1995.

Department of the Army, Headquarters. FM 3-24; Counterinsurgency. Washington, DC: U.S. Department of the Army, 2006.

Department of Defense. The 2010 Quadrennial Defense Review: Refocusing Priorities. (Washington, DC: 2010.

Duffy, Michael. "The Surge at Year One." Time Magazine. January 31, 2008. http://www.time.com/time/magazine/article/0,9171,1708843-2,00.html (accessed June 15, 2010).

Echevarria, Antulio J. Clausewitz and Contemporary War. Oxford, England: Oxford University Press, 2007.

Fitzgerald, F. Scott. “The Crack Up.” Esquire Magazine, February 26, 2008. http://www.esquire.com/features/the-crack-up (accessed 26 Sep 2010). 
Garner, Jay. “Iraq Revisited.” in Turning Victory Into Success, Military Operations After the Campaign. ed. Dr. Lieutenant Colonel Brian M. De Toy. Fort Leavenworth, KS: Combat Studies Institute Press, 2004.

Grigsby, Wayne W., Scott Gorman, Jack Marr, Joseph McLamb, Pete Schifferle, and Michael Stewart. Integrated Planning: The Operations Process, Design, and the Military Decisions Making Process. Fort Leavenworth, KS: School of Advanced Military Studies Handout, 2010.

Guthrie, General Sir Charles. "The British Army at the Turn of the Century,” RUSI Journal 141/3, June 1996. The original citation is Michael Howard, "Military Science in the Age of Peace," RUSI Journal. March 1974.

Hoffman, Frank G. Conflict in the $21^{\text {st }}$ Century, The Rise of Hybrid Wars. Potomac Institute for Policy Studies, 2007. 35. http://www.potomacinstitute.org/index.php?option=com content\&view=article\&id=77:-conflictin-the-21st-century-the-rise-of-hybrid-wars\&catid=40:books\&Itemid=62 (accessed 27 June, 2010).

Holland, John H. Adaptation in Natural and Artificial Systems. Ann Arbor, Michigan: University of Michigan Press, 1975.

Holland, John H. “Genetic Algorithms.” Scientific American, May, 2005.

Inbar, Efraim. "How Israel Bungled the Second Lebanon War.” Middle East Quarterly, Summer, 2007. http://www.meforum.org/1686/how-israel-bungled-the-second-lebanon-war (accessed 21 June, 2010).

Johnson David E. Military Capabilities for Hybrid War, Insights from the Israel Defense Forces in Lebanon and Gaza. Santa Monica, CA: RAND, 2010.

Keegan, John. The Iraq War. New York, NY: Vintage Books, 2005.

Kilcullen, David. The Accidental Guerilla. New York, NY: Oxford University Press, 2009.

Leonard, Allenna "A Response to the Discussion of the Community of Systems Thinkers and Cyberneticians.” Lecture. September 21, 2001. http://www.isss.org/911/leonard.htm (accessed 24 Sep, 2010).

Levitt, Barbara and James G. March. “Organizational Learning.” Annual Review of Sociology, August 14, 1998. http://www.knowandpol.eu/fileadmin/KaP/content/Literaturedownloablepapers/IJKL/Levitt_and_March_1988_.pdf (accessed June 23, 2010).

Liang, Qiao, Xiangsui Wang. Unrestricted Warfare. Beijing: PLA Literature and Arts Publishing House, February 1999. http://www.terrorism.com/documents/unrestricted.pdf (accessed 12 August, 2010).

March, James. Exploration and Exploitation in Organizational Learning. Stanford, CA: Graduate School of Business, Stanford University, 1991.

Matthews, Matt M. We Were Caught Unprepared, The 2006 Hezbollah-Israeli War. Fort Leavenworth, KS: Long War Series Occasional Paper 26, Combat Studies Institute Press, 2006.

Mencken, H. L. A Mencken Chrestomathy. New York, NY: A. A. Knopf, 1949.

Murphy, Jarrett. "President Declares End to Major Combat Operations in Iraq.” CBS Newsworld. May 1, 2003. http://www.cbsnews.com/stories/2003/05/01/iraq/main551946.shtml (retrieved on 16 Jun 2010).

Nagl, John A. Learning to Eat Soup With a Knife. Chicago, IL: University of Chicago Press, 2005. 
Obama, President Barack. National Security Strategy. Washington, DC: White House, 2010.

Paparone, Christopher E. "Design and the Prospects of a US Military Renaissance." Small Wars Journal (May 2010): 5-6, http://smallwarsjournal.com/blog/2010/05/print/design-and-the-prospects-of-a/ (accessed 27 June, 2010).

Record, Jeffrey. Beating Goliath, Why Insurgencies Win. Washington DC: Potomac Books, 2009.

Rich, Susan . "Trevor N. Dupuy biography.” The Dupuy Institute. http://www.dupuyinstitute.org/tndupuy.htm (accessed 24 Sep 2010).

Ryan, Alex J. “Military Applications of Complex Systems.” in Philosophy of Complex Systems. ed. Dov M. Gabbay, Cliff Hooker, Paul Thagard, John Collier and John Woods. Amsterdam, Netherlands: Elsever, 2010.

Schmitt, John F. “Command and (Out of) Control: The Military Implications Theory.” in Complexity, Global Politics, and National Security. ed. David S. Alberts and Thomas Czerwinski.

Washington DC: National Defense University, 1997. http://www.au.af.mil/au/awc/awcgate/ndu/complexity/comch09.html (Accessed 15 April, 2010).

Sun Tzu. The Art of War. Oxford, Westview Press, 1994.

Vandergriff, L. J. “Complex Venture Acquisition.” Symposium on Complex Systems Engineering. Santa Monica, CA: RAND, 2006.

Winograd Commission. "The Winograd Report: The Main Findings of the Winograd Partial Report on the Second Lebanon War.” http://online.wsj.com/public/resources/documents/winogradreport04302007.pdf (Accessed 10 Sep 2010). 